\title{
WHAT IS SPIRITUALITY?
}

\author{
K. Waaijman ${ }^{1}$
}

\begin{abstract}
This essay provides, first of all, a historical perspective on the nature of spirituality by investigating its early forms, followed by a discussion of two approaches in the last century. It then investigates three basic forms of spirituality, concluding with an overview of elements of spirituality.
\end{abstract}

\section{INTRODUCTION}

The question "What is spirituality?" is the core question of lived spirituality itself. Regarding the Christian spirituality Solignac (1990:11561160) in his survey article Spiritualité in the Dictionnaire de Spiritualité writes:

At the risk of going directly against all current opinions, we believe we must assign to the treatises concerning the spiritual life a very early date.

By "very early" he means around 200! He mentions The pedagogue of Clement of Alexandria, De oratione (On prayer) by Origen, De virginibus (On virgins) by Ambrose and De agone Christiano (The Christian combat) by Augustine. In distinction from the more speculative works intended to explain and defend dogma, people from the $3^{\text {rd }}$ century on wrote "practical works the most important aim of which is the promotion of the personal life of Christians" (Solignac 1990:1156).

When, from 1200 on, city culture began to take shape in Western Europe, and in that culture the university evolved and the JewishHellenistic-Islamic body of ideas was transformed into what would later become modern science (Grant 1996), the practice of theology emancipated itself from a system of Scripture readings and opted for a conceptual framework derived from philosophy.

1 K. Waaijman, Research Fellow, Department of New Testament, University of the Free State, Bloemfontein; and Head of the Titus Brandsma Institute, Nijmegen. 
Parallel to these processes, spirituality too began to systematise itself, culminating in a specific genre of writings which is hidden under such titles as summa, directorium, tractatus, manuale, compendium, lectio, introductio, cursus, theologia spiritualis, "overview," "fundamental themes", and so forth (Solignac 1990:1157), all of them writings which "despite their diversity in titles have the study of spiritual life in its entirety as their object" (Solignac 1990:1156). Their aim is to present in a systematic way (i.e., broadly documented, articulated in an orderly sequence, and thoroughly thought through) the phenomenon of spirituality.

In the last century only, two approaches are characteristic: the deductive one, strongly theologically oriented, and the inductive one, starting from lived experience.

The deductive approach emerged toward the end of the nineteenth century. For the first time, prefacing a treatise on the spiritual life, we then see a separate section dealing with the theological principles of the spiritual life. Meynard (1884), for example opens his Traité de la vie interrieure with an essay on the principles of the spiritual life. Asceticism and mysticism are then developed as the flowering of these theological principles which terminate under the influence of divine grace. In these treatises the principles are designated in various ways: revelation, sanctifying grace, the supernatural life, the Holy Spirit, the gifts of the Holy Spirit, participation in the divine life, the Trinity, the life of grace in Jesus Christ, the spiritual organism, and so forth. As the antecedent divine givens, these principles permeate all the spiritual themes which follow (cf. Arintero 1908; Salamanca 1930; De Smedt 1912-1913; Naval 1955; Farges 1925; Chrysogono a Jesu Sacramentato 1935; GarrigouLagrange 1938; Tonnard 1959; Dagnino 1963).

A classic example is the introduction of Tanquerey (1930), for a long time the main textbook on ascetic and mystical theology. The book consists of two parts, which immediately illustrates the paradigm shift that has taken place. The first part deals with the principles, preceded by a historical survey of the schools of spirituality. The second part discusses the three ways: the way of purgation for the beginners, the way of illumination for the advanced, and the way of union for the perfected. In this framework all the traditional spiritual themes are treated: prayer, penance, mortification, the cultivation of virtue, and so forth, 
up to and including mysticism. Under the heading of the principles the familiar issues surrounding perfection are treated: its nature, necessity, and means. Preceding this section we find a brief dogmatics in which the sources of the supernatural life and the nature of the Christian life are discussed (almost 200 pages). The tenor is clear:

This treatise then is first of all doctrinal in character and aims at bringing out the fact that Christian perfection is the logical outcome of dogma, especially of the central dogma of the Incarnation (Tanquerey 1930:v-vi).

For almost a century this dogmatic-theological approach was to control the introductions. Aumann (1980:20), quoting Gilson, stated that spirituality

will proceed dogmatically, starting from the Word of God, of which the Church is the custodian and interpreter .... Based as it is on the authority of the Word of God, the theology of the spiritual life itself proceeds by the way of authority .... It states dogmatically the laws which every authentic spiritual life ought to obey, because these laws are deduced from its origin and its end.

Beginning in the 1960s as a reaction to this dogmatic perspective of deduction, we witness a paradigm shift in the direction of experience (induction). This shift was first articulated by Truhlar (1971:8):

Spiritual theology in our day implies broad access to the awakening and development of this common substratum of experience. Spiritual theology is initiation into human life on the level of experience, an observation by which the mind, or better, man in his totality, gains contact with a content (himself, the Absolute), not via concepts but via an immediate "impression" of the presence of his own being, of the Absolute, and via his reaction as the answer of a person who takes in this impression (Truhlar 1971:19-20).

Then from within the context of this initiation into life-on-thelevel-of experience the themes of the spiritual life are arranged:

Only against the background of experience and inside of that experience the spiritual themes: prayer, work, leisure, are then treated in mystagogy (Truhlar 1971:19-20).

Truhlar offers a systematic treatment of this insight in his Concetti fondamentali della teologia spirituale. The first part entitled "La vita esperienziale" in 25 chapters treats life on the level of experience: the desire for it on the part of contemporary man; the role of spirituality as 
initiation into this life of experience; the method, nature, and basis of life on the level of experience; the socio-cultural embeddedness of it; the somatic aspects; the maturation and testing of this experience. In the second part the author treats spiritual themes which, on the basis of such an experiential starting point, call for treatment: the church and the world, Scripture and liturgy, grace and the cultivation of virtue, the reassessment of ancient means and the discovery of new ones, work and leisure, culture and everyday life.

In virtually all the newer introductions the notion of "experience" functions as a basic category. Within the field of experience we discern two approaches: the psychological and the socio-cultural approach. From the 1960s on, the psychological aspects, which had been accepted in principle in the Dictionnaire de spiritualité, ${ }^{2}$ had already come clearly into the light of day in personal initiatives ${ }^{3}$ and had conquered a modest place in the Bibliographia internationalis spiritualitatis, ${ }^{4}$ became constitutive for the study of spirituality. The socio-cultural approach, announcing its presence in periodicals and journals, has been systematically explored by the spirituality of liberation (cf. e.g., Casadáliga \& Vigil 1994; Gutiérrez 1985; Sobrino 1988; Bonnin 1984).

Our approach is a phenomenological one: going from the phenomenon to the deeper structure of this phenomenon and from the deeper structure back to the phenomenon. This essay will explain this approach in two steps. First of all there is a description of the phenomenon spirituality, followed secondly by a discussion of the basic elements of its structure.

2 Aside from the theory and history of spirituality, experimental psychology, pathology, and therapeutic psychology also were to gain a voice. See in Revue d'Ascétique et de Mystique 10 (1929).

3 J. Maréchal wrote his Études sur la psychologie des mystiques (Paris 1924 and 1937). Gabriel de St. Maria Magdalena de Pazzi pointed out the psychological aspects in the works of Teresa of Avila and John of the Cross. See Gabriel de St. Maria Magdalena de Pazzi (1936; 1940:31-42). Beginning in 1935, Père Bruno assembled in Études Carmelitaines and at the annual Congress at Avon, "the most eminent psychologists, neurologists, and psychiatrists" around diverse topics in spirituality (Beirnaert 1964:41). See also Truhlar (1961:213).

4 See BIS, section VIII, Disciplinae Adnexae, no. 4: Psychologia. 


\section{BASIC FORMS OF SPIRITUALITY - AN OVERVIEW}

Overlooking the broad phenomenon of spirituality, three basic forms can be distinguished: (1) the well established schools of spirituality; (2) primordial spiritualities such as lay spirituality, indigenous spirituality, and spirituality in secular contexts; (3) counter-movements.

\subsection{Schools of spirituality}

The most certain way to enter the field of spirituality is to look at the so-called schools of spirituality. Schools of spirituality are "historical syntheses" which display a great diversity of forms: the monastic system, the charism of Augustine, the Benedictine centuries, the regular canons, the mendicant orders, the Modern Devotion, the Jesuits, the Oratorians, the followers of Vincent de Paul, the spirituality of Grignon de Montfort, the congregations of the Passionists, Redemptionists, Salesians and the new congregation of Charles de Foucauld (1984:83-131). Mentioned in the same series are: Reformational spirituality, Orthodox spirituality, and movements like the French School (De Foucauld 1984:133-722). Aside from a diversity of forms we also encounter a multiplicity of terms used to describe the phenomenon: school of spirituality, way of spiritual life, method of spirituality, mentality, style, currents and ideal types of Christian life and holiness (Thils 1958:24-30).

We define a school of spirituality as a spiritual way that derives from a Source-experience around which an inner circle of pupils takes shape which is situated within the socio-cultural context in a specific way and opens a specific perspective on the future; a second generation structures all this into an organic whole, by means of which a number of people can share in the Source-experience. These main elements can be described in the following manner:

The Source-experience. Several studies point to the importance of the founding experience which opens a spiritual "way". It is the fundamental experience of being touched by God, an experience which touches and transforms specific people in their specific situation.

The circle of pupils. Needed for the rise of a school of spirituality is not just a Source-experience but pupils who live out of it, and give practical expression to it (Dupuy 1990:1172). The participation of the 
pupils and the Source-experience jointly give shape to a school of spirituality (Dion 1989:228; Cayré 1933:688). Only when a founder groups around him pupils who attempt to imitate him and sanctify themselves with the same means and only when one of these pupils forges the practical instructions of his teacher into a single whole, do we have the fulfillment of the conditions needed for the formation of a school of spirituality (Gautier 1953:10).

The context. In 1970 Bernard (1970:609) said:

Situated in the world and becoming conscious of himself, a human being attempts to unite himself with God. We can say, therefore, that the schools of spirituality, as types of mediation, are concretely situated in keeping with the constitutive relation of the human consciousness to itself, to the world, and to others.

The origin of a school of spirituality has to do with historical circumstances (Gaitán 1984:687-689). The historical situation makes a specific contribution to the origin, the basic concepts, and the structuring of a school of spirituality (Cf. Mataniç 1964:31ff.; Sudbrack 1969:439-440; Bernard 1970:609).

Orientation on specific values, the value system. Schools of spirituality are characterised by specific values and goals to which the school's means are adjusted. Schools, accordingly, exist to do mission work, to provide education, to take care of the sick. Within the complex of the givens of faith, accents are laid which contribute to this goal-orientation. Some schools, therefore, focus on the marial aspect, while others are more Christocentric. These special accents rarely suggest a doctrinal slant. They introduce the pupil to the value system and conceptual world of the school. They display its inner coherence and place it in the context of Christian spirituality as a whole.

A consistent whole. After the first generation, having been in direct contact with the Source-experience, gave the school of spirituality its basic form, it was the task of the second and later generations to develop it further so as to make it accessible for many more. Gradually we see coming into being an entire complex that is organically articulated inward and a resistant whole outward. This phase of the school of spirituality has been depicted in the most balanced way by De Guibert:

It is an organic whole in which none of the elements which are indispensable for spiritual advancement can be lacking and in which these 
elements can be combined in a stable and resistant equilibrium. Every school of spirituality constitutes a whole in which not a single important element can be removed, replaced, or changed without endangering the stability and sanctifying action of the whole and whose parts are not simply interchangeable with those of a neighboring school (De Guibert 1937:275; see also De Guibert 1965:48-49; Dion 1989:227-229; Morçay 1928:28).

Accessibility. More important than the question concerning the connection with the larger whole, is that concerning its accessibility. The Source-experience, after all, consisted in one or more person(s) devoting their life to the quest for God's touch. The more a school becomes a system and method (Dion 1989:229), the more the unique way of the pupil is put under pressure.

Formation in this kind of spirituality easily takes on the form of indoctrination in a theory. Everything is directed toward accepting and incorporating this spirituality into one's life but there is much less emphasis on the need to make it completely one's own (Blommestijn 1977:112-113).

Yet the process of freely appropriating what is offered in a school of spirituality constitutes the essence of the school:

A school of spirituality is the characteristic way in which a certain collectivity or period presents the spiritual journey which takes the soul to God (De Saint-Joseph 1960:116).

A school of spirituality must offer space for this journey:

It is in the interior of this space that I must discover a spiritual reality, adhere to God, and unite myself with God around it (Bernard 1970: 605-633; 605).

\subsection{Primordial spirituality}

From the perspective of the schools all forms of spirituality belong to well-established traditions. But there are also forms of spirituality which do not belong to a school. They are closely related to life as it is directly lived, connected with realities as birth, education, house, work, suffering, death. Of course, schools try to integrate this primordial spirituality, but by doing that, they admit that the primordial spirituality is originally independent, earlier than the school. 
In the field of primordial spirituality different sub-forms can be distinguished: (1) the so-called lay spirituality, or everyday spirituality, developed in the micro-world of the (extended) family; (2) the indigenous spiritualities, not yet transformed by a dominant religious tradition; and (3) forms of secular spirituality, emancipated from religious dominance. To open up the area of primordial spirituality, we limit ourselves to lay spirituality, in a diachronic perspective.

Sellner (1993:589), in his survey article Lay spirituality, correctly states: "Christian spirituality has taken many forms throughout the centuries. One important form, consistently overlooked and unappreciated, is lay spirituality."

This neglect is understandable: the area of lay spirituality - in contrast with the schools of spirituality — has scarcely been documented; the form of its tradition is mainly oral; it has no monumental buildings (monasteries; cathedrals) and libraries; it does not propagate itself in followers who live by a set of rules (Kelly 1980; Finn 1990; GarciaMateo 1995). To enter the area of lay spirituality, we follow - paradigmatically — the land map of the Old Testament.

In his study Persönliche Frömmigkeit und offizielle Religion, Rainer Albertz shows how, in the context of the family, which in the patriarchal stories (Gen. 12-50) is the sustaining form of community, a kind of personal (not individualistic) piety was cultivated. This spirituality was defined by a relation to God in which God is called "my Mighty One" ('elohai), that is, in which God is addressed as the God who shapes everyone in his or her mother's womb, causes them to be born and leads them throughout life. This is evident from their proper names, prayers, and stories. This personal relation to God is experienced within the spirituality of the community as a whole: at the time of birth and death, on the occasion of the naming and the weaning of the child, in the child's upbringing and at the time of marriage, upon entering new pasture grounds and leaving them, at the time of sickness and dangers, in the context of assemblies and mutual helpfulness. This form of spirituality obtains its religious connections from

the field of experience in which it belongs: the family. What an individual person hopes for and experiences from God has its frame of reference in what he has experienced in the years of his childhood from his parents in terms of love, affection, and security (Albertz 1978:76). 
In the period in which families united in tribal associations which broke the supremacy of Egypt and the Canaanite city states, as well as in the period of the state of Israel under the Davidic dynasty, lay spirituality was pushed into the background. The official religion which was "primarily activated in the annual festivals (macro-cultic) of the great sanctuaries" (Albertz 1978:12) became dominant. Lay spirituality, however, characteristically remained distinct from Yahwist religion and its official institutions (Albertz 1978:92). In stories, prayers, and names the personal relation to God was continued within the frame of reference of the family.

When the great story of the official religion lost its credibility as a result of the destruction of Jerusalem (587 B.C.), "the piety of the family was much less affected by it" and "now gained a significance for the people as a whole which far surpassed the family circle" (Albertz 1978:165). We observe how lay spirituality supplied the matrix for the survival of the crisis of the exile (Albertz 1978:178-90). Exilic texts show paradigmatically how personal piety can take over a decisive function from official religion when the latter has entered a crisis (Albertz 1978:169).

Following the exile lay spirituality continued to play an important role (Albertz 1978:190-8). We can see that in deuteronomistic spirituality. Aside from the ordinances which apply to the people as a whole, there are rules for the family: the house that has to be built and in which the family lives; agriculture; family life, mutual solidarity; upbringing; fertility and birth; sickness and death. Also the second temple makes space for the perspective of lay piety, as we can see in the collection of pilgrim songs (Pss.120-124; Albertz 1978:169-78). In the exile, moreover, a new spiritual form had developed: the house of study. The foundation of the house of study was the ability to read. After the destruction of the Second Temple, this form of learning as well as the fact that the elite had lost its infrastructure (the temple) caused Jewish spirituality predominantly to remain a lay spirituality.

This short survey reveals the following structural elements of lay spirituality: (1) There is reference to a specific web of relations described as relational fields such as husband-wife, parents-children, nuclear family-extended family, family-acquaintances, and so forth. (2) These relational patterns are realised in specific periods described in words 
like genealogy (succeeding generations) and course of life (a process, however phased, between birth and death). (3) These relational patterns have their focal point in the home which, on the one hand, creates intimacy inward, and, on the other mediates the connections with the environment (labour, possessions, socio-religious participation, hospitality). (4) Central is the individual person in his or her existential concreteness.

\subsection{Counter-spirituality}

A counter-movement denotes a power which offers a counterplay or counterweight against an existing power configuration. Counter-movements in spirituality are legion.

The origin of Israel is connected with a counter-movement arising from the wilderness: oppressed farmers, shepherds, and stateless people took action against the Egyptian dominance of the Middle East. Prophets like Elijah, Micah, and Jeremiah formed a counter-movement against kings who violated the rights of the people. Holy fools, dissidents, anchorites, and exiles form a constant counter current against established relations. Mary's Magnificat, Francis's Ode to the sun, Pascal's Thoughts, and Buber's $I$ and thou are all counter-voices which continue to undermine the self-delusion of power.

Counter-movements in spirituality are found outside the sphere of power structures and established relations: outside of their concepts, their spatial orders, their time period, their hierarchies, their great narratives. But they do not let themselves be locked up in this "outside" state. They swim against the current.

We can elucidate the phenomenon of spiritual counter-movements from within the field of tension called "structure - anti-structure" which Victor Turner described in order to explain cultural processes in preliterate cultures, but also in Western culture. By "structure" he means a coherent whole of social roles and positions which functions in accordance with legitimated norms and sanctions. Anti-structure is the area outside of this: fruitful chaos, a place of incubation for new ideas. Turner (1974:231-271) distinguishes three forms of antistructure: liminality, inferiority, and marginality. 
This three-part division can help explore the field of spiritual countermovements in further detail.

Liminal spirituality. Following Arnold van Gennep, Victor Turner (1974:231-233, 151-153) distinguishes three phases which play a role in every rite of passage. There is the phase of separation (a person or group is detached from the social structure), the phase of liminality (individuals find themselves outside of the social structure in a state of indeterminacy) and the phase of reintegration (individuals are again incorporated in the social structure). Liminality is no unmixed blessing to be in, since those who are in it are literally nowhere: outside the established cadres, outside of any time frame. Death, darkness, and nothingness prevail here. Liminal entities are tabulae rasae, without possessions, passive. Yet there is a current of life here: creativity, community, equality, vital energy, insight, imagination, wholeness, naturalness. Liminality is marked by the continual alternation between death and life. Liminal entities experience the extremes of ordinary life: the most profound experience of being valued and the most intense experience of being devalued; the intense experience of meaning and the experience of being made totally ridiculous. From within this transitional phase of liminality arise forms of spirituality which develop outside the established cadres of culture: the spirituality of the slaves who fled Egypt and went into the wilderness; the spirituality of the exile; the spirituality of the desert monks; the spirituality of poverty movements; the spirituality of the Jews who were driven out of Spain and Portugal; holocaust spirituality; end-time spiritualities. However, one can also call to mind here the spirituality that is lived in the loneliness of modern mass culture; the spirituality which is developed outside the standard cadres of religious or humanistic institutions.

Inferior spirituality. "Inferiority" is the position of those who find themselves on the underside of the social pyramid or, even lower, in the cellars of humankind: the outcast, the unemployed, the unskilled worker, the impoverished, the court jester, the misshapen, the "strange bird", the handicapped, the child, the woman in a patriarchal society. This position can be described in terms of destitution (without status, power, or identity). At the same time people attribute a certain power to this position. Inherent in it is a sharp insight into society. It functions as a symbol of humanity. It is experienced as being endowed 
with a kind of divine power which can turn everything upside down. It is regarded as authentic and natural (the shepherd, the beggar, the savage, the primitive; Cf. Turner 1969:234-235).

The "inferiority" of the early Christian communities was expressed by Paul as follows:

Just consider your own call, brothers. Not many of you were wise by human standards, not many were powerful, not many were of noble birth. But God chose what was foolish in the world to shame the wise. God chose what is weak in the world to shame the strong. God chose what is low and despised in the world, things that are nothing to reduce to nothing things that are something (1 Cor. 1:26-28).

The early Hassidic groups in Eastern Europe occupied an inferior position in the Judaism of that day. They were not schooled in Torah and Talmud, were not far removed from folk religiosity, followed divergent customs and leaned strongly toward popular traditions of ecstasy and mass enthusiasm.

Marginal spirituality. Marginality is a position marked by a double loyalty. On the one hand, marginals belong to a given prestigious group in society. That is where they live; that is where their chances of advancement are located; that is their frame of reference. On the other hand, they are connected by their origin with groups outside, or on the underside, of society. Examples are: second-generation immigrants, children of the déclassé, migrants from the countryside to the city, women in emancipated positions, artists with recognised status (Turner 1969: 233). By their double loyalty they can offer radical criticism of the structures of society from the inside. One frequently finds them among writers, artists, and philosophers. Their positions make them well-suited to keep alive the human conscience.

In the history of spirituality we observe this marginality in mendicant brothers who have become rich: Francis continues to attend to the necessary unrest. We also find it in prophetic movements which remember Israel's liminal origins (in the wilderness). Christian spirituality always carries with it the "dangerous memory" of the cross. 


\section{ELEMENTS OF SPIRITUALITY}

Reflecting on the basic forms of spirituality and listening to the basic words used in these forms to articulate what spirituality is about, we find the following three elements.

\subsection{A relational process between God and man}

All forms of spirituality seem to point to a relational process between God and man. The accent falls one moment on the divine pole (the Awesome, the Holy, the Merciful, the Infinite One), the next on the human pole (application, dedication, awakening). These poles are not first considered separately and then related to each other, but constitute an original relational whole within which the two poles make their appearance. In spirituality the goal is not to name or define the divine pole. It appears within the whole of the relational process in accordance with the phase in which this process finds itself: as wholly other than the finite, as awesome touch, as an unfolding of power in which a human being shares, as Spirit who animates our spirit. The views held concerning God and the divine names must be understood in light of the relational process in which they function. Also the human pole must be read in light of this process. In accordance with its position in the spiritual process the human pole is touched and made to tremble, applies itself to the search for God, devotes itself fervently to God, makes itself receptive and allows itself to be purified, appropriates God's life to itself, lets itself be transported outside of itself in love, and that on all the levels of existence. Through this relational process its original wholeness and ultimate maturity comes to light.

\subsection{A gradual process}

The two poles interlock: for humans the divine emanations form the way back to God; God's abundant mercy takes shape in human works of mercy; God's holiness is received by believers in the sanctification of their life. As a result of this reciprocity human conduct is both active and passive: God's mercy is received in deeds of mercy; the fear of God trembles at the Secret to which it reaches out; the knowledge of God is God-given knowledge. 
The relation between God and man is a process extending from the very first awesome touch to respectful love; from living in the commonplace world to being completely consumed in the reality of God; from the ultimate emanation of God to a state of attachment to the Infinite; from original wholeness to complete maturity. The original wholeness of man looks forward to a complete surrender-in-love; the human spirit finds its completion in union with the Spirit of God; the divine core reaches its resting place when it breathes along with the self-giving of the Father.

\subsection{Transformation}

The relational process is realised in the substance of human existence: the intellect (knowledge, attention, awakening, contemplation), the will (devotion, attachment, kawwana, fervency, inwardness), the memory, control of one's drives, lifestyle, the ordering of time and space, social interaction, the religious life, culture.

The intimacy of the relational process and the concentration which flows from it effects a contraction in that which is peculiar to itself (its own language and logic, inwardness, mysticism, kabbala) and a dissociation from the prevailing patterns (the world, instrumental rationality, that which has been secularised and objectified, the unmerciful, externality).

\section{CONCLUSION}

The phenomenon of spirituality appears as a complex whole, constructed out of elements which are complementarily interrelated. Spirituality is a relational process which constitutes an original whole in which God and man are reciprocally related.

(1) The relational process can be viewed from the standpoint of the divine pole: God communicates himself; on the way to this divine self-communication man appropriates for himself God's truth and worth in order to become perfect in God. It can also be viewed from the standpoint of the human pole: humans in various ways prepare themselves for union with God in order to grow in the direction of perfection in God. 
(2) The relational process is layered: the whole of human experience (the faculties, affectivity, praxis) is involved in it on a personal, social, and socio-cultural level (the perspective of experience). This is a phased process marked by several transitions.

(3) The relational process is mediated: there are forms which serve as intermediaries to take humans in the direction of God (forms of knowing, willing, acting, and so forth) and forms which serve as intermediaries to bring God in the direction of man (Scripture, sacraments, the neighbour, and so forth).

\section{BIBLIOGRAPHY}

AlbertZ R

1978. Persönliche Frömmigkeit und offizielle Religion. Stuttgart.

ARINTERO J

1930. Evolución mistica. Salamanca.

AUMANN J

1980. Spiritual Theology. Huntington-London.

\section{BEIRNAERT L}

1964. Expérience chrétienne et psychologie. Paris.

BERNARD C

1970. Médiations spirituelles et diversité des spiritualités. Nouvelle Revue Theologique 102:609.

\section{BLOMMESTIJN H}

1977. Spiritualiteit en hoe je jezelf kunt bedriegen. Speling 29:112-113.

BONNIN E

1984. Spiritualität und Befreiung in Latein Amerika. Würzburg.

Casadáliga P \& Vigil J

1994. Political holiness. A spirituality of liberation. New York. 


\section{CAYRÉ F}

1933. Écoles de spiritualité. In: F. Cayré, Patrologie et histoire de la théologie 2. (Paris), p. 688.

\section{Chrysogono A Jesu Sacramentato} 1935. Asceticae et mysticae Summa. Rome.

\section{DAGNINO A}

1963. La vita interiore secundo la Rivelazione. Studiata della theologia e insegnata della chiesa. Milano.

\section{De Foucauld C}

1984. Le grandi scuole della spiritualità cristiana (ed. E. Ancilli). Roma-Milano.

\section{De GUIBERT J}

1937. Theologia spiritualis. Rome.

\section{De SAINT-JosepH L}

1960. École de spiritualité. In: Dictionnaire de Spiritualité 4:116.

\section{De SMedt C}

1912-1913. Notre vie surnaturelle. Son principe, ses facultés, les conditionis de sa pleine activité (1910-1911). Brussels.

\section{DION M}

1989. La spiritualité ignatienne. Église et Théologie 20:228.

\section{DUPUY M}

1990. Spiritualité. II. La notion de spiritualité. In: Dictionnaire de Spiritualité $14: 1172$.

\section{FARGES A}

1925. Les voies ordinaires de la vie spirituelle. Paris.

\section{FINN V}

1990. Pilgrims in this world. A lay spirituality. New York.

\section{Gabriel De St. Maria Magdalena De Pazzi}

1936. École thérésienne et problèmes mystiques contemporaines. Brussels.

1940. Indole psicologica della teologica spirituale. Rivista di Filosofia Neoscolastica 32:31-42.

GARRIGOU-LAGRANGE R

1938. Les trois âges de la vie intérieure. Traité de théologie ascétique et mystique. Paris.

\section{GAITÁN J}

1984. Espiritualidad y espiritualidades. Revista de Espiritualidad 43:687-689.

\section{GAUTIER J}

1953. La spiritualité catholique. Paris. 
Acta Theologica Supplementum 8

Garcia-Mateo R

1995. Teologia spirituale. Il laicato. Rome.

\section{GRANT E}

1996. The foundation of modern science in the Middle Ages. Cambridge.

GutiérRez G

1985. We drink from our own wells. The spiritual journey of a people. New York.

\section{KELLY B}

1980. Lay spirituality. Its theory and practice. London.

\section{MARÉCHAL J}

1924; 1937. Études sur la psychologie des mystiques. Paris.

\section{MATANIÇ A}

1964. Le scuole di spiritualità nel magistero pontifico. Brescia.

\section{MeYnard A}

1884. Traité de la vie intérieure ou petite somme de la théologie ascétique et mystique. Clermont-Ferrand.

\section{MORÇAY R}

1928. Les écoles de spiritualité vers la piété moderne. In: Études religieuses. LiègeParis.

1928. Les écoles de spiritualité chrétienne. La pensée catholique. Liège-Paris.

\section{NAVAl F}

1955. Curso de teologia ascética y mistica (1914). Madrid.

\section{SELLNER E}

1993. Lay spirituality. In: The New Dictionary of Catholic Spirituality, p. 589.

\section{SeYbold K}

1978. Die Wallfahrtpsalmen. Neukirchen-Vluyn.

\section{SOBRINO J}

1988. Spirituality of liberation. Toward political holiness. New York.

\section{SOLIGNAC A}

1990. Spiritualité. I. Le mot et l'historie. DSp 14:1156-1160.

\section{SUDBRACK J}

1969. Letzte Norm des Ordenslebens ist die im Evangelium dargelegte Nachfolge

Christi. Geist und Leben 42:439-440.

\section{TANQUEREY A}

1930. The spiritual life. A treatise on ascetical and mystical theology. Tournai et al.

\section{THILS G}

1958. Sainteté chrétienne. Tielt. 
Waaijman

What is spirituality?

TONNARD F

1959. Traité de la vie spirituelle. Paris.

Truhlar C

1961. Structura theologica vitae spiritualis. Rome.

1971. Concetti fondamentali della teologia spirituale. Brescia.

TURNER V

1969. The ritual process. Structure and anti-structure. London.

1974. Dramas, fields, and metaphors. London.

VANDENBROUCKE F

1965. Spiritualiteit en spiritualiteiten. Concilium 1:48-49.

Keywords

Spirituality

Forms of spirituality

Schools of spirituality

Counter-spirituality
Trefwoorde

Spiritualiteit

Vorme van spiritualiteit

Skole van spiritualiteit

Kontra-spiritualiteit 